\title{
Kristin Hausler*
}

k.hausler@biicl.org

orcid.org/0000-0002-2655-5026

British Institute of International and Comparative Law

17 Russell Square, London WC1B 5JP, United Kingdom

\section{The EU Approach to Cultural Heritage in Conflict and Crisis: An Elephant in the Room?}

\begin{abstract}
This Note considers the Conclusions on EU Approach to Cultural Heritage in Conflicts and Crises, which were adopted by the Council of the European Union on 21 June 2021. It starts by analysing the shift in the way cultural heritage has been perceived since the introduction of cultural heritage within the EU's external relations' strategy. It then considers how the role of cultural heritage as a vector of peace and development could be strengthened and consolidated through a better articulation of its linkages with climate change.
\end{abstract}

Keywords: cultural heritage, traditional knowledge, climate change, EU external relations, peace and security

\footnotetext{
* Kristin Hausler is the Director of the Centre for International Law and Dorset Senior Fellow at the British Institute of International and Comparative Law in London. She holds a Bachelor and Master of Law from the University of Fribourg (Switzerland) and an LL.M. from the University of British Columbia (Canada). She regularly provides advice on cultural heritage matters, including on the drafting of heritage laws, as well as training on heritage protection. She has also taught cultural heritage law at universities around the globe. Before joining the Institute, she worked at the Museum of Anthropology in Vancouver on a project repatriating Ancestral remains to Indigenous communities.
} 


\section{LEGAL COMMENTARIES}

Kristin Hausler

On 21 June 2021, the Council of the European Union approved its Conclusions on EU Approach to Cultural Heritage in Conflicts and Crises ("Conclusions"), ${ }^{1}$ which were preceded by a Concept on Cultural Heritage in Conflicts and Crises prepared by the European External Action Service (EEAS). ${ }^{2}$ These latest Council Conclusions, which contribute to the strategic approach of the European Union (EU) to peace, security, and development, mark a rather significant shift in the manner in which cultural heritage may be integrated within the EU's external action since the adoption by the European Commission of its Joint Communication to the European Parliament and the Council "Towards an EU Strategy for International Cultural Relations" in 2016 ("2016 Joint Communication"). ${ }^{3}$ At the time, the work streams envisaged as including cultural heritage specifically within the EU's external relations were restricted to research, the combat of trafficking, and its protection, with cultural heritage being described as "fragile and often threatened by natural disasters, man-made destruction such as wars, looting and pillaging". ${ }^{4}$ While culture more generally was conceived as a driver for development and inter-cultural dialogue and considered as a tool for peace-building, no measures specifically pertaining to cultural heritage were set out to include those aims. ${ }^{5}$

In 2017, following up on the 2016 Joint Communication, the Council provided some general guidance on the EU's strategic approach to international cultural relations, but without elaborating further on cultural heritage. ${ }^{6}$ Cultural heritage became the focus of the Council in 2018 when it highlighted the need to bring it "to the fore across policies in the EU". ' However, the potential role of cultural heritage within the EU's external relations was not further considered, with the Council then only inviting Members States and the Commission "to continue to support cultural heritage as an important element in the EU's strategic approach to international cultural relations as well as in the promotion of intercultural dialogue". ${ }^{8}$

1 Council of the European Union, Council Conclusions on EU Approach to Cultural Heritage in Conflicts and Crises, 21 June 2021, 9837/21.

2 European External Action Service (EEAS), Concept on Cultural Heritage in Conflicts and Crises. A Component for Peace and Security in European Union's External Action, 18 June 2021, 9962/21.

3 European Commission, Joint Communication to the European Parliament and the Council: Towards an EU Strategy for International Cultural Relations, 8 June 2016, JOIN(2016) 29 final.

4 Ibidem, p. 12.

5 For an earlier note on this point by this author, see Cultural Heritage within the European Union's External Relations: More than a Policy Objective?, in: A. Jakubowski, K. Hausler, F. Fiorentini (eds.), Cultural Heritage in the European Union: A Critical Inquiry into Law and Policy, Brill Nijhoff, Leiden 2019, p. 381.

6 Council conclusions on an EU strategic approach to international cultural relations, OJ C 189, 15.06.2017, p. 38.

7 Council conclusions on the need to bring cultural heritage to the fore across policies in the EU, OJ C 196, 8.06.2018, p. 20.

8 Ibidem, para. 15. Its Paragraph 16 also invited them "to implement common and coordinated transnational actions with international organisations to safeguard and preserve cultural heritage in a sustainable manner and in line with the 2030 Agenda for Sustainable Development". 
In 2019, the Council further simply recognized the need to "develop partnerships with international organisations and institutions that promote the role of culture and cultural heritage in bringing peace to conflict and post-conflict areas".

In 2021, the Council eventually expanded its conceptualization of the potential role of cultural heritage within external relations in a significant manner. While the threats to cultural heritage were still naturally highlighted, its possible role as an "important vehicle for peace" was also firmly recognized..$^{10}$ This approach builds on the Council Conclusions on EU Peace Mediation adopted the previous year, which had emphasized "the importance of cultural heritage in conflict prevention and resolution". ${ }^{11}$ Since its mention in the 2016 Joint Communication, the perspective on cultural heritage has therefore been the object of a dramatic and welcome shift: from a vulnerable asset considered exclusively through the prism of protection, to a driver of peace and development. While the role cultural heritage can play in peace-building has yet to be further articulated, the Conclusions adopted in 2021 already demonstrate a significant evolution.

It is noteworthy that cultural heritage as a vector for sustainable development is also included in the Conclusions. Although cultural heritage was included in the Sustainable Development Goals (SDGs), ${ }^{12}$ it was only explicitly mentioned in Target 11.4 with regard to the need to protect and safeguard the world's cultural heritage. Development projects are still too often at odds with the preservation of cultural heritage, at times even damaging or leading to the destruction of heritage. ${ }^{13}$ In particular, although development actors, including financial institutions, have often adopted policies and processes that safeguard tangible cultural heritage, the possible negative impact of development projects on intangible forms of cultural heritage is still not sufficiently taken into consideration. ${ }^{14}$ In that regard, the fact that the Council stressed "the complementarity and interlinkages that can exist between intangible and tangible heritage" may support a better integration of intangible cultural heritage considerations within the

\footnotetext{
9 Council conclusions on an EU strategic approach to international cultural relations and a framework for action, OJ C 192, 7.06.2019, p. 6, para. 43.

10 Council of the European Union, Council Conclusions on EU Approach..., para. 2.

11 Council of the European Union, Council Conclusions on EU Peace Mediation, 7 December 2020, 13573/20, para. 10.

12 Note that Goal 4 mentions "cultural diversity" and that Goals 8 and 12 include targets that refer to "local culture"; see S. Labadi et al., Heritage and the Sustainable Development Goals: Policy Guidance for Heritage and Development Actors, ICOMOS, Paris 2021.

13 See, for example, the case of the ancient city of Hasankeyf in B. Drazewska, Hasankeyf, the llisu Dam, and the Existence of "Common European Standards" on Cultural Heritage Protection, "Santander Art \& Culture Law Review" 2018, Vol. 2(4), pp. 89-120.

14 B. Drazewska, K. Hausler, The Role of Multilateral Development Banks (MDBs) in the Protection of Intangible Cultural Heritage, BIICL Working Paper, 2020.
} 


\section{LEGAL COMMENTARIES}

Kristin Hausler

development sector, as well as within the protection sector, where the focus has so far also remained on tangible cultural heritage. ${ }^{15}$

More generally, the Council calls for an "inclusive, equal and non-discriminatory approach" and "stresses the importance of local ownership and the need to place local communities' needs and participation at the centre of the efforts". ${ }^{16}$ This is of particular importance inasmuch as many jurisdictions continue to approach cultural heritage governance with a top-down perspective, which may not always support the needs and wishes of minority communities with regard to their cultural heritage. It is also in line with the human rights approach to cultural heritage, which was also highlighted by the Council. ${ }^{17}$

However, overall, the focus of the Council remains perhaps too firmly geared towards the protection of cultural heritage, with too few mentions of the ways cultural heritage can support the EU in addressing conflicts and crises. For example, it underlines 'the importance of coordination between Member States' respective instruments and initiatives to improve the ability to respond quickly in relation to the protection of cultural heritage and preventing its destruction". ${ }^{18}$ Of course, protecting cultural heritage may allow it to be a vector for peace and providing protection measures may by themselves support peacebuilding. However, other measures should be considered in order for cultural heritage to reach its potential as a vector for peace and development, including for example educational measures. When talking about integration into the $\mathrm{EU}$ toolbox for conflicts and crises, once again cultural heritage protection is mentioned, but not cultural heritage in itself. ${ }^{19}$ Similarly, when inviting relevant EU bodies to exchange best practices and develop expertise, the focus is placed on protection. ${ }^{20}$ Reference is also specifically made to the "Responsibility to Protect", which may in itself be questioned given its failure so far to prevent major occurrences of atrocity crimes. ${ }^{21}$ However, the reference to it in the Conclusions may at least serve as a reminder that attacks against cultural heritage may not only amount to war crimes but also to persecution, a type of crime against humanity, as well as serve to demonstrate an intent to commit genocide.

In addition, although the focus of the Conclusions is on cultural heritage protection, a few gaps in the field have yet to be addressed more comprehensively. For example, although the Council calls for protection at "all stages" of conflicts

\footnotetext{
15 Council of the European Union, Council Conclusions on EU Approach..., para. 5.

16 Ibidem, paras. 4 and 7.

17 Ibidem, para. 8.

18 Ibidem, para. 10.

19 Ibidem, paras. 10-11.

20 Ibidem, para. 14.

21 Ibidem, para. 6.
} 
and crises, it then elaborates specifically on the protection of cultural heritage "in the aftermath of a conflict of crisis", ${ }^{22}$ without confronting the gaps in protection during an armed conflict itself, i.e. when cultural heritage may be most at risk of damage or destruction. In particular, it would have been worth highlighting the need to consider possible further engagements with armed non-state actors in the protection of cultural heritage. Although such groups have often ignored the rules pertaining to the need to respect cultural properties, several of them have demonstrated interest in being trained in the field and in the application of heritage protection measures. ${ }^{23}$ Furthermore, it should also be underlined that transition periods in the "aftermath of a conflict" often give rise to an opportunity to strengthen the legal provisions pertaining to cultural heritage protection. At that time, supporting local legislative bodies may ensure that newly adopted laws improve the protection of all forms of cultural heritage, as well as its governance.

While the Council rightly raises the issue of "illegal excavation, looting and trafficking of cultural property", it first associates it with security threats owing to the possibility of cultural property being used to support terrorism financing. It is only afterwards that it notes that such acts can have "a socio-cultural impact, as it is a political tool to weaken communities and identities". ${ }^{24}$ Although there is some evidence that looting may have provided financial means to support terrorism activities, ${ }^{25}$ there is not at present sufficient evidence to affirm that antiquities trafficking has been a significant source of terrorism financing. ${ }^{26}$ Given that the link between trafficking and terrorism financing may be somewhat discredited, it would be preferable if its socio-cultural impact was highlighted first. Furthermore, illegal excavation and looting should also be considered as a form of destruction of cultural heritage, because such actions generally erase both provenience as well as all the scientific data which may be associated with it and which may contain valuable information. While the Import Regulations adopted in $2019^{27}$ may raise the chances

\footnotetext{
22 Ibidem, para. 3.

23 M. Lostal, K. Hausler, P. Bongard, Culture under Fire: Armed Non-State Actors and Cultural Heritage in Wartime, Geneva Call, Geneva 2018.

24 Council of the European Union, Council Conclusions on EU Approach..., para. 12.

25 See, for example, M.J. Sison, Explanation of Vote at the Adoption of UN Security Council Resolution 2347 on the Destruction and Trafficking of Cultural Heritage by Terrorist Groups, 24 March 2017, https://usun.usmission.gov/explanation-of-vote-at-the-adoption-of-un-security-council-resolution-2347-on-the-destruction-and-trafficking-of-cultural-heritage-by-terrorist-groups/ [accessed: 15.01.2022].
}

26 See in particular M. Sargent et al., Tracking and Disrupting the Illicit Antiquities Trade with Open Source Data, Homeland Security Operational Analysis Center operated by the RAND Corporation, Santa Monica, CA 2020, https://www.rand.org/content/dam/rand/pubs/research_reports/RR2700/RR2706/ RAND_RR2706.pdf [accessed: 15.01.2022], which challenges the widely held view that trafficking is a major source of terrorism financing; also see A.M. de Jong, The Cultural Goods Import Regime of Regulation (EU) 2019/880: Four Potential Pitfalls in this issue of the "Santander Art and Culture Law Review", pp. 31.

27 Regulation (EU) 2019/880 of the European Parliament and of the Council of 17 April 2019 on the introduction and the import of cultural goods, OJ L 151, 7.06.2019, p. 1. 


\section{LEGAL COMMENTARIES}

Kristin Hausler

that a looted object will be returned to its country of origin, it is likely that by then its heritage value will already be largely diminished as a result of missing provenience details. Therefore, perhaps more efforts should be made to combat looting at the source, such as with the use of satellite imagery, ${ }^{28}$ and include the local capacity-building already mentioned and envisaged in the Conclusions. Furthermore, the restitution of looted cultural heritage should be more specifically considered as a possible support for peace-building and development at the Union level. ${ }^{29}$

But there is perhaps an even bigger issue that needs confronting, and which may thus appear as somewhat of an elephant in the room or, at least, as a missing piece of the puzzle. Despite the Conclusions' adoption of a holistic approach and its welcome expansion of the role of cultural heritage in addressing conflicts and crises, and even though the Conclusions are framed by the issue of peace and security, they fail to clearly acknowledge climate change as a driver of conflict and crisis. It is surprising given that the EU has identified climate change as a security issue for over a decade and has recently increased its budget for climate action to ensure the mainstreaming of climate in all its programmes. ${ }^{30}$ Although the EEAS called "to factor the interlinkages between the effects of climate change and natural and cultural heritage in the EU's engagement", its focus was on the risks faced by cultural heritage, which is not dissimilar to the approach to cultural heritage as a vulnerable asset requiring protection, as conceived in the 2016 Joint Communication. ${ }^{31}$ This limited perspective was adopted by the Council, which recognized in its Conclusions "the need to support measures which aim to mitigate the negative impacts of climate change on natural and cultural heritage", the only instance climate change is mentioned therein, almost in passing. ${ }^{32}$

Reiterating the warning issued by the EU in 2008, the Special Rapporteur in the Field of Cultural Rights stated in her 2020 Annual Report that: "Climate change is a 'threat multiplier' which magnifies existing threats to cultural heritage, such as by fuelling poverty, political instability and resource conflicts in which heritage destruction may take place". ${ }^{33}$ It should therefore be clearly highlighted

\footnotetext{
28 European Commission, op. cit., p. 12.
}

29 For more on the issue and current gaps, see the European Parliament resolution of 17 January 2019 on cross-border restitution claims of works of art and cultural goods looted in armed conflicts and wars (2017/2023(INI)), OJ C 411, 27.11.2020, p. 125.

30 High Representative and the European Commission, Climate Change and International Security, Paper for the Council of the European Union, 14 March 2008, p. 2; see also Council of the European Union, Council Conclusions on Climate Diplomacy, 20 January 2020, 5033/20, para. 10.

31 EEAS, op. cit., p. 10.

32 Council of the European Union, Council Conclusions on EU Approach..., para. 5. Note also the current work of the European Commission which is gathering experts to share good practices on the protection of heritage from the effects of climate change, see Council conclusions on the Work Plan for Culture 2019-2022, OJ C 460, 21.12.2018, p. 12.

33 UN General Assembly, Report of the Special Rapporteur in the Field of Cultural Rights, Karima Bennoune, 10 August 2020, UN Doc. A/75/298, para. 26. 
in any document concerned with cultural heritage. In addition, cultural heritage can also play an important role in mitigation and adaptation and therefore should also be considered as a "climate asset". ${ }^{44}$ In particular, the Conclusions appear to ignore the potential role of "traditional knowledge", which should be understood as part of cultural heritage, in providing climate resilience. Although local knowledge is mentioned in the definition of intangible cultural heritage offered by the EEAS, ${ }^{35}$ the more specific term of "traditional knowledge" is not. Traditional knowledge is defined by the World Intellectual Property Organization as the "knowledge, know-how, skills and practices that are developed, sustained and passed on from generation to generation within a community, often forming part of its cultural or spiritual identity". ${ }^{36}$ This knowledge of natural events results from the intimate relations that communities, often Indigenous communities, enjoy with the lands they inhabit. Its valuable role in disaster risk reduction and preparedness has been widely recognized. ${ }^{37}$ As it can "inform our understanding of climate impacts" and "should be considered as a complement to science", 38 the Special Rapporteur recommended to:

Fully explore the potential of culture and cultural heritage and traditional, indigenous and local knowledge to enhance mitigation and adaptation efforts; and promote awareness of and respect for rights-respecting traditional knowledge, including its importance in responding to the climate emergency. ${ }^{39}$

This has also already been recognized by States when they adopted the Paris Agreement in 2015, in which they acknowledged that:

adaptation action [...] should be based on and guided by the best available science and, as appropriate, traditional knowledge, knowledge of indigenous peoples and local knowledge systems, with a view to integrating adaptation into relevant socioeconomic and environmental policies and actions, where appropriate..$^{40}$

34 Ibidem, para. 67.

35 EEAS, op. cit., p. 3. Note that the Council only mentions "the transmission of traditions and knowledge" when discussing the "importance of engaging on intangible heritage as a way to build common understanding", Council of the European Union, Council Conclusions on EU Approach..., para. 5.

36 See the website of the World Intellectual Property Organization at https://www.wipo.int/tk/en/tk/ [accessed: 15.01.2022].

37 See the Guiding Principles of the Sendai Framework for Disaster Risk Reduction 2015-2030 (UN General Assembly, Resolution 69/283: Sendai Framework for Disaster Risk Reduction 2015-2030, 23 June 2015, UN Doc. A/RES/69/283, para. 19(g)), which states that disaster risk reduction must be based on scientific information "complemented by traditional knowledge".

38 UN General Assembly, Report..., para. 68.

39 Ibidem, para. 81(i).

40 UN Framework Convention on Climate Change, Report of the Conference of the Parties on Its Twenty-First Session, Held in Paris from 30 November to 13 December 2015, 29 January 2016, UN Doc. FCCC/CP/2015/10/ Add.1, Paris Agreement, Article 7, para. 5. 


\section{LEGAL COMMENTARIES}

Kristin Hausler

Therefore, in order to fully harness the potential of cultural heritage as a vector for peace, democracy, and development, the European Union should further articulate the relationship between cultural heritage, and in particular traditional knowledge, and climate change. ${ }^{41}$ This would also allow to affirm the role of cultural heritage as an asset within the EU's climate diplomacy, which includes all actions taken by this organization to develop international cooperation with regard to climate change mitigation and adaptation. ${ }^{42}$ While the EU seeks to mainstream climate across its programmes, cultural heritage should be fully integrated into those efforts, which is not yet the case. For example, when the European Parliament called for a strengthening of the EU capacity for climate diplomacy, it mentioned that Indigenous peoples "play an active and vital role in protecting the ecosystems in which they live, thereby mitigating the effects of climate change" but it did not specifically mention traditional knowledge or cultural heritage more widely. ${ }^{43}$ As the EU seeks to deliver security, it should also do so by supporting the strengthening of local resilience to climate change, ${ }^{44}$ including through the support for the integration of cultural heritage in mitigation and adaptation measures. Therefore, while the Conclusions adopted by the Council in 2021 can be lauded as a substantial step forward in the conceptualization of cultural heritage as more than just a valuable asset deserving of protection, there is yet more work ahead to ensure all of its facets are utilized in addressing crises, starting with the biggest crisis of our time: the climate crisis.

\section{References}

Bremberg N., EU Foreign and Security Policy on Climate-related Security Risks, Stockholm International Peace Research Institute, 2019.

Council conclusions on an EU strategic approach to international cultural relations, OJ C 189, 15.06.2017, p. 38.

Council conclusions on an EU strategic approach to international cultural relations and a framework for action, OJ C 192, 7.06.2019, p. 6.

Council conclusions on the need to bring cultural heritage to the fore across policies in the EU, OJ C 196, 8.06.2018, p. 20.

41 For more on the potential role of climate change with regard to mitigation and adaptation, see, for example, ICOMOS Climate Change and Cultural Heritage Working Group, The Future of Our Pasts: Engaging Cultural Heritage in Climate Action, ICOMOS, Paris 2019, https://indd.adobe.com/view/a9a551e3-3b234127-99fd-a7a80d91a29e [accessed: 25.01.2022].

42 N. Bremberg, EU Foreign and Security Policy on Climate-related Security Risks, Stockholm International Peace Research Institute, 2019, p. 3.

43 European Parliament, Report on Climate Diplomacy, 26 June 2018, P8_TA(2018)0280, p. 5.

44 N. Bremberg, op. cit., p. 5. 
Council conclusions on the Work Plan for Culture 2019-2022, OJ C 460, 21.12.2018, p. 12.

Council of the European Union, Council Conclusions on Climate Diplomacy, 20 January 2020, $5033 / 20$.

Council of the European Union, Council Conclusions on EU Approach to Cultural Heritage in Conflicts and Crises, 21 June 2021, 9837/21.

Council of the European Union, Council Conclusions on EU Peace Mediation, 7 December 2020, 13573/20.

Drazewska B., Hasankeyf, the llisu Dam, and the Existence of "Common European Standards" on Cultural Heritage Protection, "Santander Art \& Culture Law Review" 2018, Vol. 2(4).

Drazewska B., Hausler K., The Role of Multilateral Development Banks (MDBs) in the Protection of Intangible Cultural Heritage, BIICL Working Paper, 2020.

European Commission, Joint Communication to the European Parliament and the Council: Towards an EU Strategy for International Cultural Relations, 8 June 2016, JOIN(2016) 29 final.

European External Action Service (EEAS), Concept on Cultural Heritage in Conflicts and Crises. A Component for Peace and Security in European Union's External Action, 18 June 2021, 9962/21.

European Parliament, Report on Climate Diplomacy, 26 June 2018, P8_TA(2018)0280.

European Parliament resolution of 17 January 2019 on cross-border restitution claims of works of art and cultural goods looted in armed conflicts and wars (2017/2023(INI)), OJ C 411, 27.11.2020, p. 125.

Hausler K., Cultural Heritage within the European Union's External Relations: More than a Policy Objective?, in: A. Jakubowski, K. Hausler, F. Fiorentini (eds.), Cultural Heritage in the European Union: A Critical Inquiry into Law and Policy, Brill Nijhoff, Leiden 2019.

High Representative and the European Commission, Climate Change and International Security, Paper for the Council of the European Union, 14 March 2008.

ICOMOS Climate Change and Cultural Heritage Working Group, The Future of Our Pasts: Engaging Cultural Heritage in Climate Action, ICOMOS, Paris 2019, https://indd.adobe. com/view/a9a551e3-3b23-4127-99fd-a7a80d91a29e [accessed: 25.01.2022].

Labadi S. et al., Heritage and the Sustainable Development Goals: Policy Guidance for Heritage and Development Actors, ICOMOS, Paris 2021.

Lostal M., Hausler K., Bongard P., Culture under Fire: Armed Non-State Actors and Cultural Heritage in Wartime, Geneva Call, Geneva 2018.

Regulation (EU) 2019/880 of the European Parliament and of the Council of 17 April 2019 on the introduction and the import of cultural goods, OJ L 151, 7.06.2019, p. 1.

Sargent M. et al., Tracking and Disrupting the Illicit Antiquities Trade with Open Source Data, Homeland Security Operational Analysis Center operated by the RAND Corporation, Santa Monica, CA 2020, https://www.rand.org/content/dam/rand/pubs/research_reports/RR2700/RR2706/RAND_RR2706.pdf [accessed: 15.01.2022].

Sison M.J., Explanation of Vote at the Adoption of UN Security Council Resolution 2347 on the Destruction and Trafficking of Cultural Heritage by Terrorist Groups, 24 March 2017, https:// usun.usmission.gov/explanation-of-vote-at-the-adoption-of-un-security-council-resolution-2347-on-the-destruction-and-trafficking-of-cultural-heritage-by-terroristgroups/ [accessed: 15.01.2022]. 


\section{LEGAL COMMENTARIES}

Kristin Hausler

UN Framework Convention on Climate Change, Report of the Conference of the Parties on Its Twenty-First Session, Held in Paris from 30 November to 13 December 2015, 29 January 2016, UN Doc. FCCC/CP/2015/10/Add.1, Paris Agreement.

UN General Assembly, Report of the Special Rapporteur in the Field of Cultural Rights, Karima Bennoune, 10 August 2020, UN Doc. A/75/298.

UN General Assembly, Resolution 69/283: Sendai Framework for Disaster Risk Reduction 2015-2030, 23 June 2015, UN Doc. A/RES/69/283. 